\title{
Effects of Various Types of Extracellular Matrices on Adhesion, Proliferation, Differentiation, and c-fos Protein Expression of Porcine Thyroid Follicle Cells
}

\author{
Shuji Toda ${ }^{1}$, Sueo Matsumura ${ }^{2}$, Nobuhisa Yonemitsu ${ }^{1}$, Noboru Fujitani ${ }^{3}$, Kiyomi Terayama ${ }^{1}$, \\ Sadayuki Funatsumaru ${ }^{1}$, and Hajime Sugihara ${ }^{1}$ \\ Department of Pathology ${ }^{1}$ and Biochemistry ${ }^{2}$, Saga Medical School, Nabeshima, Saga 849, Japan; and Depart- \\ ment of Legal Medicine ${ }^{3}$, Kurume University School of Medicine, Kurume 830, Japan
}

Key words: Thyroid follicle cells/Extracellular matrix/Integrin/Thyrotropin/c-fos protein/In vitro

\begin{abstract}
Thyroid follicles in vivo are embedded in extracellular matrix (ECM). The composing epithelial cells are in close contact with ECM at the basal side. To examine cell-to-ECM interactions, we studied adhesion, proliferation and differentiation of porcine follicle cells monolayer-cultured on type I and IV collagen, fibronectin or laminin. At $3 \mathrm{~h}$ in culture, laminin had the lowest rate of cell adhesion. In proliferation, type IV collagen induced the highest level of nuclear bromodeoxyuridine intake. In a functional differentiation, laminin had about 3 times as much triiodothyronine production as the other ECM molecules. In confluent culture cells, we also examined an expression of c-fos protein, a transcription factor that plays crucial roles in signal transduction. Immunocytochemistry detected the protein mainly in the nuclei. Western blot showed that laminin induced the highest level of its expression. Thyrotropin (TSH, $10 \mathrm{mU} / \mathrm{ml}$ ) did not affect adhesion of the cells on any of the substrata or proliferation of the cells on fibronectin; nor did TSH affect c-fos protein expression of the cells on the substrata except for fibronectin. Our results suggest that type IV collagen and laminin, major components of basement membrane, play positive roles in proliferation and differentiation of follicle cells, respectively, while laminin has no positive effect on adhesion of the cells at early culture; that the cells express cfos protein even in contact inhibition of growth and its expression is regulated in part by ECM; and that ECM controls some behaviors of the cells in a TSH-dependent or TSH-independent manner.
\end{abstract}

Extracellular matrix (ECM) plays vital roles in both embryonic morphogenesis and regulation of cell behaviors in adult tissues, involving adhesion, migration, proliferation and differentiation of many cell types $(22,18$, 19). Recently, many studies and ours have shown that gel of type I collagen, a major component of ECM, induces structural and/or functional differentiation of multiple cell types, including thyroid follicle cells $(8,11$, $13,16,20,21,25,30-33,38-40,45)$. In thyroid gland, individual follicles, its structural and functional unit, are embedded in interfollicular ECM (3). At the basal side, composing epithelial cells are in close contact with the intricate network of ECM containing mainly type I collagen and fibronectin through basement membrane, which consists chiefly of type IV collagen, laminin, and

Address all correspondence and requests for reprints to: Shuji Toda $^{1 *}$, M.D., Ph.D., Department of Pathology, Saga Medical School, Nabeshima 5-1-1, Saga 849, Japan.

Abbreviations: ECM, Extracellular matrix; PBS, Phosphate buffered saline; FCS, Fetal calf serum; TSH, Thyrotropin; BrdU, Bromodeoxyuridine; $\mathrm{T}_{3}$, Triiodothyronine; RIA, Radio-immunoassay; ABC, Avidin-biotin complex; PAG, Polyacrylamide gel; KD, Kilodalton; $\mathrm{VLA}_{3}$, Very late antigen 3 . heparan sulfate proteoglycans (24). Each of the ECM components is thus expected to play crucial roles in regulating the behaviors of follicle cells. To ultimately clarify pathogeneses of human thyroid disorders, it is, therefore, essential to study follicle cell-to-ECM interactions. However, it has not yet been examined what effects on the cells various ECM components induce. To estimate the roles of ECM, we have studied the effects of type I and IV collagen, fibronectin and laminin on the adhesion, proliferation and differentiation of porcine thyroid follicle cells in monolayer cultures with plastic substratum (polycation-coated dish) as a reference.

Protein c-fos is encoded by the c-fos oncogene which is the cellular cognate of $\mathrm{v}$-fos, the transforming gene of the FBJ-murine osteosarcoma virus $(10,14)$. This oncoprotein is a transcription factor that regulates proliferation and differentiation of many cell types $(1,9,29)$. In thyroid follicle cells, recent studies indicate that c-fos mRNA expression is transiently enhanced in proliferation of the culture cells without contact inhibition of growth $(6,17,35,41)$. However, it has hardly been examined whether the level of c-fos protein is actually in- 
creased in these cells. The effects of ECM components on c-fos protein expression of follicle cells are also unknown. In addition, follicle cells in normal thyroid essentially have low mitotic ability $(5,12)$. To clarify the roles of c-fos protein other than proliferation, it is essential to study the protein expression in the cells under such a situation as would be simulated by contact inhibition of growth in vitro. To estimate an expression of cfos protein in cell-to-ECM interaction, we performed immunocytochemical and Western blot analyses for the protein in follicle cells confluently cultured on different types of ECM components.

For the first time, we show herein that each type of the ECM components has crucial effects on the biological behaviors of thyroid follicle cells.

\section{MATERIALS AND METHODS}

Preparation of ECM-coated culture dishes. Type I and IV collagen (Nitta Gelatin Co., Ltd., Osaka, Japan) were diluted by $\times 30$ with $1 \mathrm{mM} \mathrm{HCl}$ to the final concentration of $100 \mu \mathrm{g}$ $/ \mathrm{ml}$. Fibronectin and laminin (Nitta Gelatin Co., Ltd.) were diluted by $\times 40$ with water to the final concentration of 12.5 $\mu \mathrm{g} / \mathrm{ml}$. Using these matrix solutions, ECM-coated dishes were prepared by the following standard method. After 6, 1 and $0.036 \mathrm{ml}$ of the matrix solutions were placed on $100 \mathrm{~mm}$ - and $35 \mathrm{~mm}$-diameter culture dishes, and 96 well dishes, respectively, the culture dishes were kept at $25^{\circ} \mathrm{C}$ for $1 \mathrm{~h}$. The solutions were removed and dried overnight at $25^{\circ} \mathrm{C}$. Type I and IV collagen-coated dishes were washed twice with phosphate-buffered saline (PBS) immediately before use. In addition to these ECM substrata, plastic substratum (polycation-coated culture dish, Corning Costar Corporation, Cambridge, MA) was used as a reference substratum in this study.

Cell culture. Isolated thyroid follicle cells from 6-monthold porcine were prepared as described elsewhere (38). These cells had no contamination with smooth muscle cells or fibroblasts. The cells were cultured in ECM-coated or plastic dishes with Ham's F-12 medium supplemented with 5\% fetal calf serum (FCS) and $50 \mu \mathrm{g} / \mathrm{ml}$ gentamicin. Some cultures were stimulated with $10 \mathrm{mU} / \mathrm{ml}$ thyrotropin (TSH, Sigma, St. Louis, MO).

Assay of cell adhesion. To examine the effects of different substrata on adhesion of follicle cells, $1.5 \times 10^{5}$ cells were seeded and cultured in ECM-coated or plastic dishes $(35 \mathrm{~mm}$ diameter) for $3 \mathrm{~h}$ with or without $10 \mathrm{mU} / \mathrm{ml} \mathrm{TSH}$. The culture dishes were aspirated and washed three times with Ham's F-12 medium. The adherent cells were trypsinized and processed by the standard method, and were counted with a Coulter Counter (Coulter Electronics, Inc., Hialeah, FL), as previously described (38). The rate of cell adhesion was calculated as follows: the number of adherent cells $/ 1.5 \times 10^{5} \times 100(\%)$. In addition, at 6,24 or $48 \mathrm{~h}$ in culture, we calculated the rate of adherent cells on each substratum by the same method. These results in part also involved those of proliferation of the cells cultured on each substratum.

Assay of cell proliferation. To estimate the effects of different substrata on proliferation of follicle cells, we performed immunocytochemical assay in microtiter plate wells, using monoclonal anti-bromodeoxyuridine (BrdU) antibody to detect BrdU incorporated in cellular DNA (cell proliferation assay kit, Amersham, Arlington Heights, IL). This kit has high sensitivity in detection of cell proliferation with wide range of cell number $\left(1 \times 10^{3}\right.$ to $\left.1 \times 10^{5}\right)(4)$. The proliferation assay was carried out after the rates of cell adhesion reached to about $90 \%$ (see Fig. 2). After $100 \mu \mathrm{l}$ cell suspension containing 5,000 cells were seeded in each of 96 wells, the cells were cultured for $24 \mathrm{~h}$ in type I collagen-, type IV collagen-, fibronectin-coated, or plastic wells, and cultured for $48 \mathrm{~h}$ in laminin-coated wells. After $100 \mu l$ labeling medium $(30 \mathrm{mg} / \mathrm{ml}$ $\mathrm{BrdU}$ ) was added to each well, the cells were cultured for $2 \mathrm{~h}$ with or without $10 \mathrm{mU} / \mathrm{ml} \mathrm{TSH}$. The culture cells were fixed with $30 \%$ acetic ethanol and processed according to the protocol of the kit. The absorbance of each well was measured at $410 \mathrm{~nm}$.

Assay of triiodothyronine $\left(T_{3}\right)$ in culture medium. In this study, we selected $T_{3}$ production as an indicator of differentiation of follicle cells, because porcine follicle cells stably produce $T_{3}$ in culture. To estimate the effects of different substrata on $\mathrm{T}_{3}$ production of follicle cells, $6 \times 10^{5}$ cells were first cultured in ECM-coated or plastic dish ( $35 \mathrm{~mm}$-diameter) until they formed a confluent monolayer within 1-2 days. After the medium was exchanged for fresh medium and the cells were cultured for $48 \mathrm{~h}$ with or without a $12 \mathrm{~h}$-stimulation of $10 \mathrm{mU} / \mathrm{ml} \mathrm{TSH}, \mathrm{T}_{3}$ secretion from follicle cells into medium was assessed in culture supernatants by the standard radio-immunoassay (RIA) method ( $\mathrm{T}_{3}$ assay kit, Dinabot Co., Ltd., Tokyo, Japan).

Immunocytochemical and Western blot analyses for c-fos protein. On 4 days in culture, we observed the effects of different substrata on $\mathrm{c}$-fos protein expression in confluent culture cells under contact inhibition of growth, a condition simulating low mitotic ability of follicle cells in normal thyroid $(5,12)$. At first, $6 \times 10^{5}$ (for immunocytochemistry) and $42 \times 10^{5}$ (for Western blotting) cells were cultured on different substrata in $35 \mathrm{~mm}$ - and $100 \mathrm{~mm}$-diameter dishes, respectively until they formed a confluent monolayer within 1-2 days. After 2 days in culture, the medium was exchanged for fresh medium and the cells were cultured for $48 \mathrm{~h}$ with or without a $12 \mathrm{~h}$-stimulation of $10 \mathrm{mU} / \mathrm{ml} \mathrm{TSH}$. Before the detection of cfos protein, we also confirmed by phase contrast microscopy that the culture cells were completely confluent. Using the culture cells, we performed immunocytochemistry and Western blotting with anti-c-fos polyclonal antibody (Ab-2, Oncogene Science, Inc., Uniondale, NY). In immunocytochemistry, after culture cells were fixed for $5 \mathrm{~min}$ by $3.7 \%$ paraformaldehyde/PBS, air-dried and processed by the standard methods, the cells were incubated with anti-c-fos antibody for $1 \mathrm{~h}$ at $25^{\circ} \mathrm{C}$. The protein was detected by the avidin-biotin complex immunoperioxidase (ABC) method. We also examined immu- 

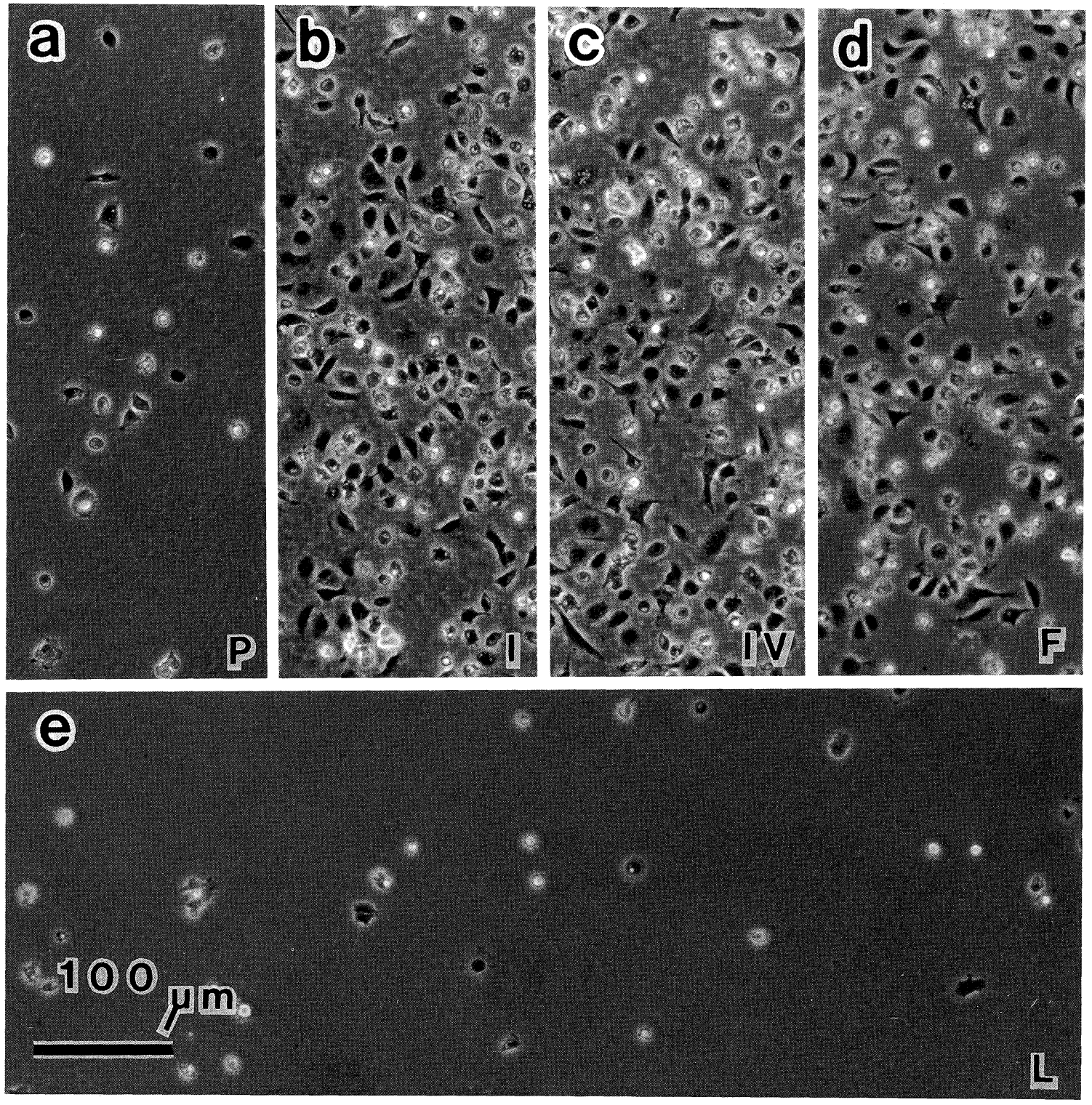

Fig. 1. Phase contrast micrograph of follicle cells cultured on different substrata at $3 \mathrm{~h}$ in culture. Type I (I, b) and IV collagen (IV, c), and fibronectin $(F, d)$ induce good outcomes of cell adhesion and spreading, while plastic substratum $(P, a)$ has poorer results of those. Laminin $(L, e)$ shows the poorer cell adhesion and has cell spreading similar to plastic substratum.

nohistochemically the distribution of c-fos protein in normal thyroid on sections of $3.7 \%$ paraformaldehyde/PBS-fixed tissues. To examine whether this immunostaining was specific for c-fos protein, we performed an absorption test as a negative control. The c-fos antibody $(1 \mu \mathrm{g})$ neutralized with c-fos antigen (10 $\mu \mathrm{g}$, peptide- 2 , Oncogene Science, Inc.) was used in- stead of a primary antibody and processed by the same methods above. For Western blotting, after the culture cells were washed twice with cold PBS, in the dishes the cells were suspended in $0.6 \mathrm{ml}$ of $0.1 \mathrm{M}$ Tris- $\mathrm{HCl}(\mathrm{pH} 6.8)$ containing $2 \%$ sodium dodecyl sulfate (SDS) and 5\% 2-mercaptoethanol. The samples were boiled for $20 \mathrm{~min}$ and then centrifuged for

Fig. 2. Rates of cell adhesion in follicle cells cultured on different substrata. At $3 \mathrm{~h}$ in culture, rates of cell adhesion to type I (I) and IV collagen (IV), and fibronectin (F) are about 60\%, respectively, while those of adhesion to laminin (L) and plastic substratum (P) are about 8 and $30 \%$, respectively ( $\mathrm{P}<0.001$ between I, IV or $\mathrm{F}$ and $\mathrm{L}$ or $\mathrm{P} ; \mathrm{P}<0.001$ between $\mathrm{L}$ and $\mathrm{P}$ ). In continuous culture, the rate of cell adhesion to each substratum gradually increases. The rates of adhesion to the substrata except for laminin $(\mathrm{L})$ reach to about $90 \%$ at $24 \mathrm{~h}$ in culture, while the rate of adhesion to laminin $(\mathrm{L})$ reached to almost the same range at $48 \mathrm{~h}$. TSH $(10 \mathrm{mU} / \mathrm{ml})$ does not affect the rates of adhesion of cells cultured on any of the substrata. The values represent the mean \pm S.D. of five independent experiments. 

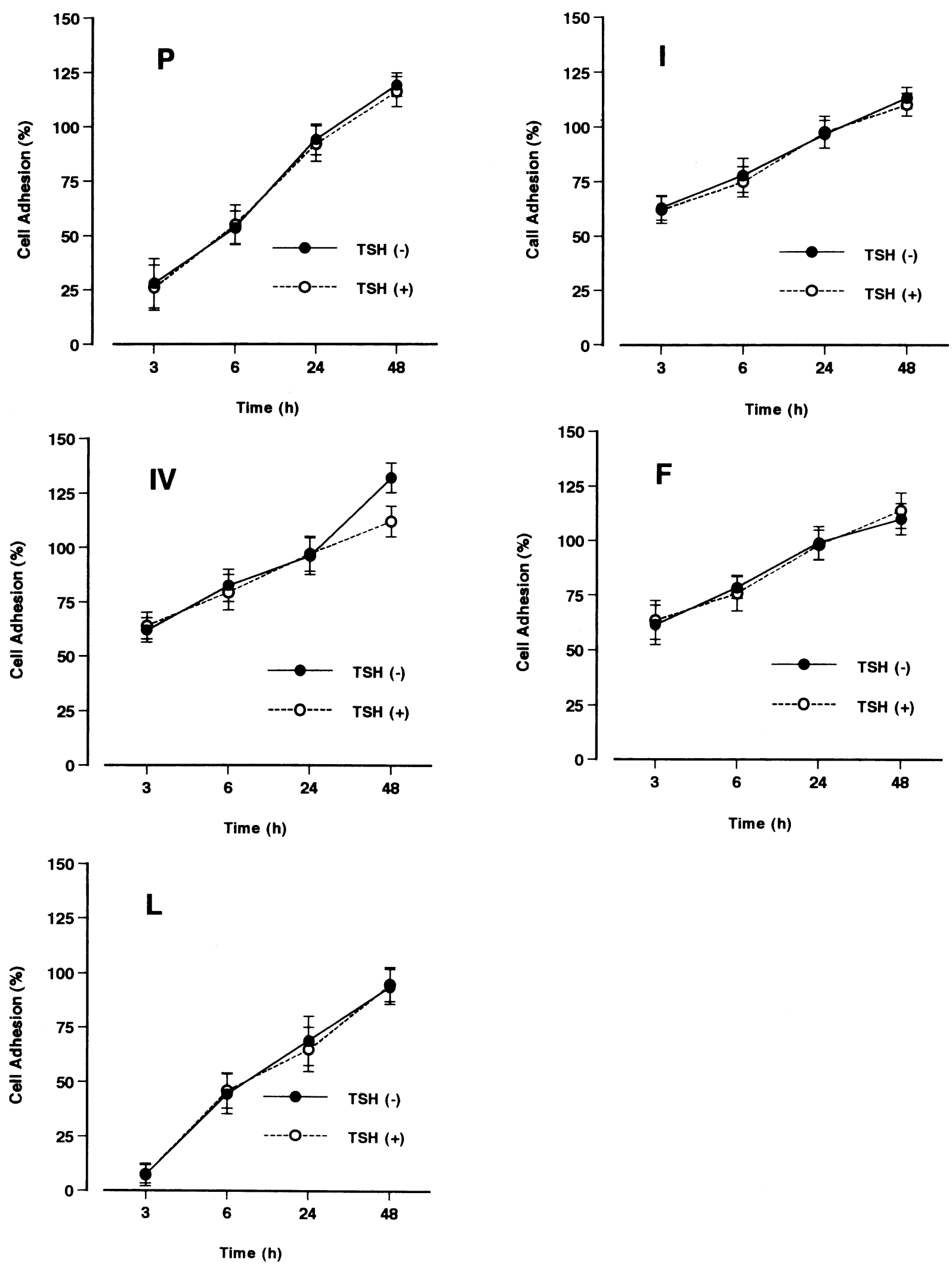

Fig. 2 . 


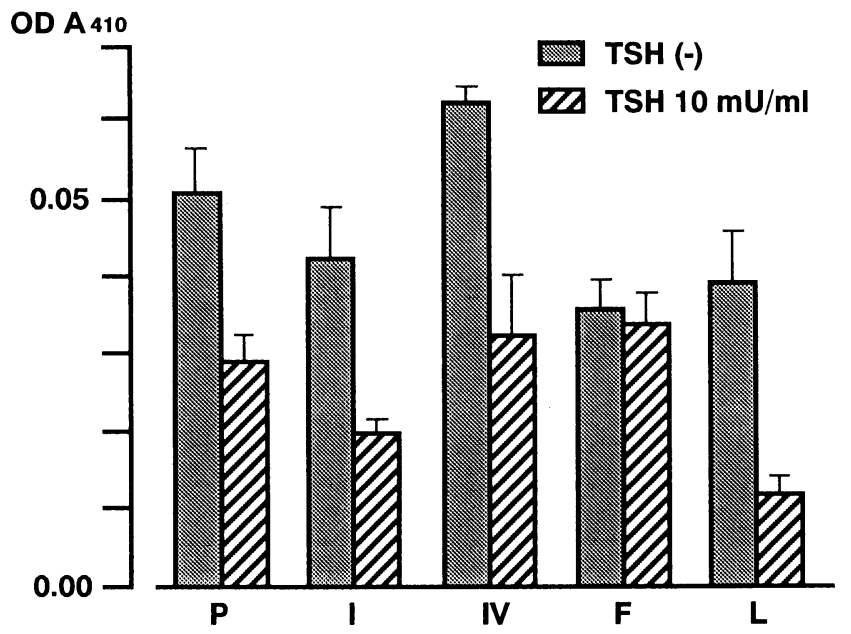

Fig. 3. Nuclear BrdU intake of follicle cells cultured on various substrata. Type IV collagen (IV), plastic substratum (P) and type I collagen (I) induces the higher intake of BrdU in that order, as compared with fibronectin $(\mathrm{F})$ and laminin $(\mathrm{L})$, although there is no statistical significance between type IV collagen (IV) and plastic substratum (P) or type I collagen (I). There is statistical significance only between type IV collagen (IV) and fibronectin (F) or laminin (L) $(\mathrm{P}<0.02$ between IV and F; $\mathrm{P}<0.05$ between IV and $\mathrm{L})$. TSH $(10 \mathrm{mU} / \mathrm{ml})$ clearly inhibits the BrdU intake of cells cultured on any of the substrata except for fibronectin (F). TSH does not suppress the BrdU intake of the cells cultured on fibronectin $(F)$. The values represent the mean \pm S.D. of five independent experiments.

10 min. Twenty $\mu l$ of the solubilized proteins were subjected to electrophoresis on $10 \%$ polyacrylamide gel (PAG), and then transferred to a nitrocellulose membrane sheet (Bio-Rad, CA). The antigen on the membrane was visualized according to the manual supplied by Bio-Rad, using the ABC method.

Statistical analyses. We performed statistical analyses of the data obtained through four or five independent experiments, using student's $\mathrm{t}$ test. $\mathrm{P}<0.05$ was considered significant.

\section{RESULTS}

Cell adhesion. The results of adhesion assays were as follows. At $3 \mathrm{~h}$ in culture, the rates of cell adhesion to type I and IV collagen, and fibronectin were all about $60 \%$. In contrast, the rates of cell adhesion to laminin and plastic substratum were about 8 and 30\%, respectively (Figs. 1 and 2). At this culture time, laminin and plastic substratum induced poor cell spreading (Fig. 1, a and e). In continued culture, the rate of cell adhesion to each substratum gradually increased. The rates of adhesion to the substrata except for laminin reached to

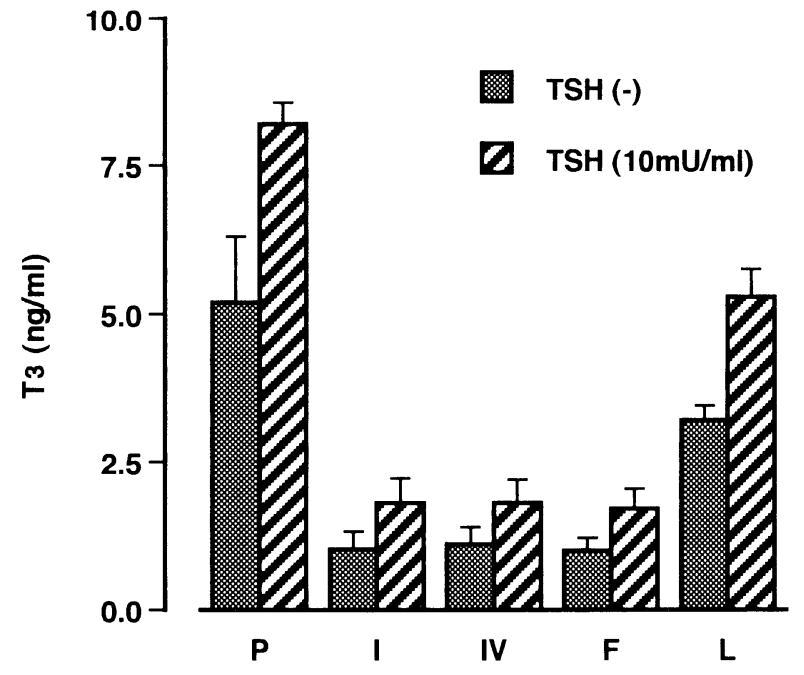

Fig. 4. $T_{3}$ production of follicle cells cultured on various substrata. Laminin (L) shows about 3 times as much $\mathrm{T}_{3}$ production as type I (I) and IV collagen (IV), and fibronectin (F) $(\mathrm{P}<0.01$ between $\mathrm{L}$ and I, IV or F). Plastic substratum (P) has the highest level of $\mathrm{T}_{3}$ production and shows about 1.6 times the production of laminin $(\mathrm{L})(\mathrm{P}<0.05$ between $\mathrm{P}$ and $\mathrm{L})$. TSH $(10 \mathrm{mU} / \mathrm{ml})$ clearly increases $\mathrm{T}_{3}$ production from cells cultured on each substratum. The values represent the mean \pm S.D. of four independent experiments.

about $90 \%$ at $24 \mathrm{~h}$ in culture, while adhesion to laminin reached to almost the same range at $48 \mathrm{~h}$ (Fig. 2). The rates of cell adhesion to all substrata or cell spreading exhibited no differences with or without $10 \mathrm{mU} / \mathrm{ml}$ TSH (Fig. 2). Finally, cells cultured on type I and IV collagen, fibronectin or plastic substratum seemed to enter the proliferative phase after $24 \mathrm{~h}$ in culture, while adhesion of cells on laminin was almost completed at $48 \mathrm{~h}$ and thereafter the cells were expected to come into the proliferative phase (Fig. 2). In addition, none of the cells cultured on the substrata had distinctive differences in morphology except for cell spreading.

Cell proliferation. The proliferation assay was performed after the rate of cell adhesion to each substratum reached to about $90 \%$ (Fig. 2). In nuclear BrdU intake of culture cells, type IV collagen was the highest, and then came plastic substratum, type I collagen, laminin and fibronectin in that order (Fig. 3). In fact, the number of the cells cultured on type IV collagen was highest after $48 \mathrm{~h}$ (see Fig. 2). In these values, there was statistical significance only between type IV collagen or plastic substratum and fibronectin or laminin. TSH (10 $\mathrm{mU} / \mathrm{ml}$ ) clearly inhibited nuclear BrdU intake of the cells cultured on each substratum except for fibronec-

Fig. 5. Immunocytochemistry for c-fos protein. Immunocytochemistry shows that c-fos protein is localized in the nuclei of cells cultured on laminin (a). An absorption test results in negative staining for this protein (b). In the porcine thyroid (c and d), c-fos product is also positive immunostained in the nuclei (arrowhead) of some follicle cells and is also weakly stained in some cytoplasms (arrow). Most smooth muscle cells of blood vessels are positive-stained in both nuclei (arrowhead) and cytoplasms (arrow). The staining intensity is stronger in smooth muscle cells than in follicle cells. 
S. Toda et al.

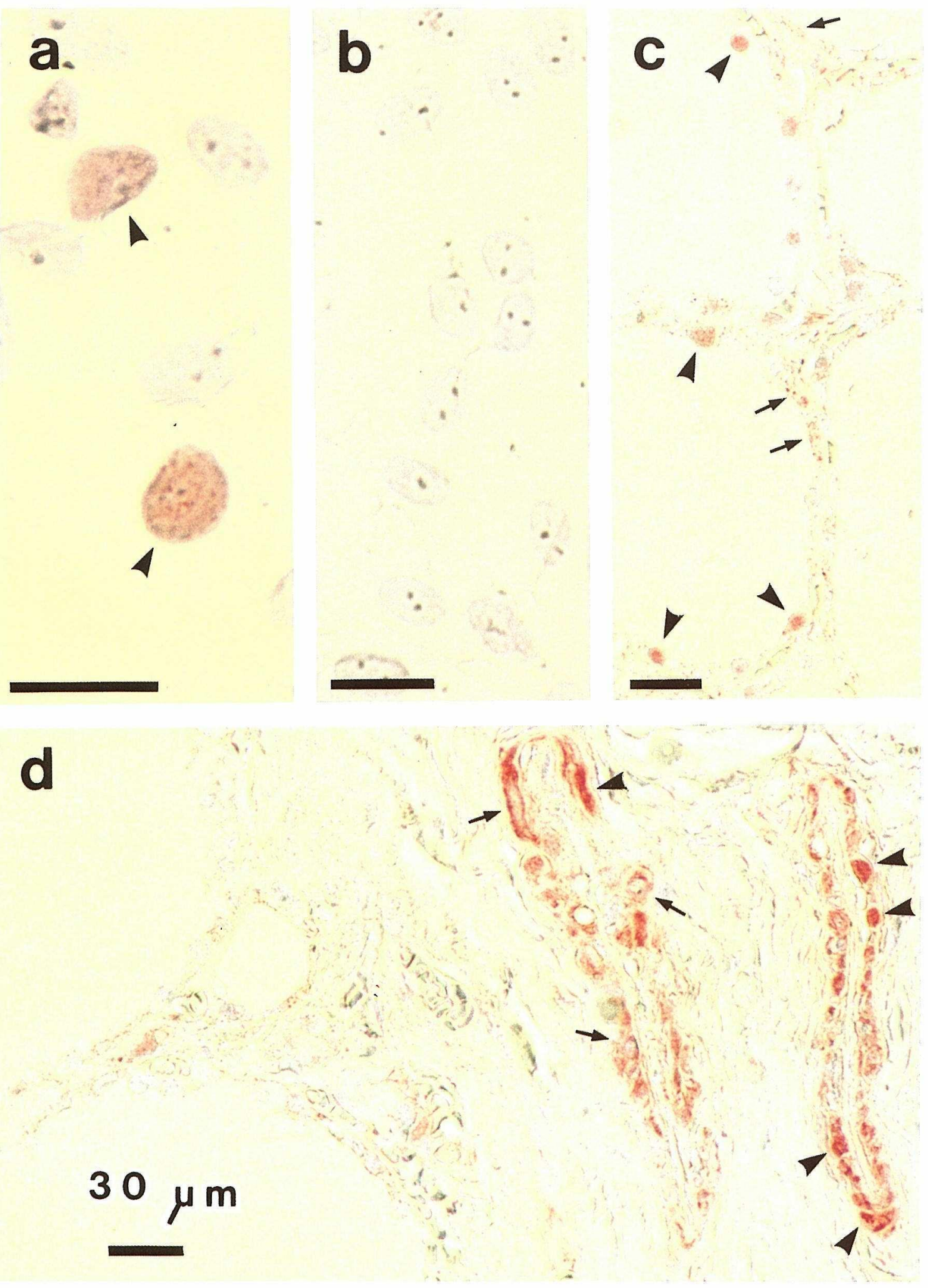

Fig. 5. 
tin. Interestingly, the BrdU intake of cells cultured on fibronectin was not suppressed by TSH (Fig. 3).

$T_{3}$ production. To examine the effects of various substrata on the differentiation of follicle cells, we assayed $T_{3}$ in culture supernatants at 4 days in culture. Laminin had about 3 times as much $\mathrm{T}_{3}$ production as type I and IV collagen, and fibronectin. However, plastic substratum induced the highest $\mathrm{T}_{3}$ production and showed about 1.6 times the production of laminin (Fig. 4). TSH $(10 \mathrm{mU} / \mathrm{ml})$ clearly increased $T_{3}$ production from the cells cultured on each substratum (Fig. 4). in addition, after 8-10 days in culture, none of the cells cultured on each substratum had any significant differences in $T_{3}$ production. This suggested that at the late culture stage, the cells themselves may newly produce ECM molecules and fall into almost the same ECM-environment.

Expression of c-fos protein. To estimate c-fos protein expression of follicle cells in cell-to-ECM interaction under contact inhibition, we performed immuno- cytochemistry and Western blotting for the protein. In immunocytochemistry, c-fos protein was detected mainly in nuclei of some cells cultured on each substratum even in contact inhibition (Fig. 5a), although weakly positive staining was observed in cytoplasms of some cells (data not shown). An absorption test resulted in negative staining (Fig. $5 \mathrm{~b})$. TSH $(10 \mathrm{mU} / \mathrm{ml})$ did not appear to affect the expression of c-fos protein in any of the cells cultured on the substrata when examined immunocytochemically. In thyroid tissue, c-fos protein was detected mainly in the nuclei of some follicle cells, and was occasionally and weakly seen in cytoplasms (Fig. 5c). Most smooth muscle cells of blood vessels were positively stained in nuclei and cytoplasms (Fig. 5d). The staining intensity was stronger in smooth muscle cells than in follicle cells (Fig. 5, c and d). Western blotting of the cell extracts showed that cells cultured on various substrata each contained slightly different levels of c-fos product of 62 kilodalton (KD) (Fig. 6). Cells cultured on laminin appeared to express the highest level of the

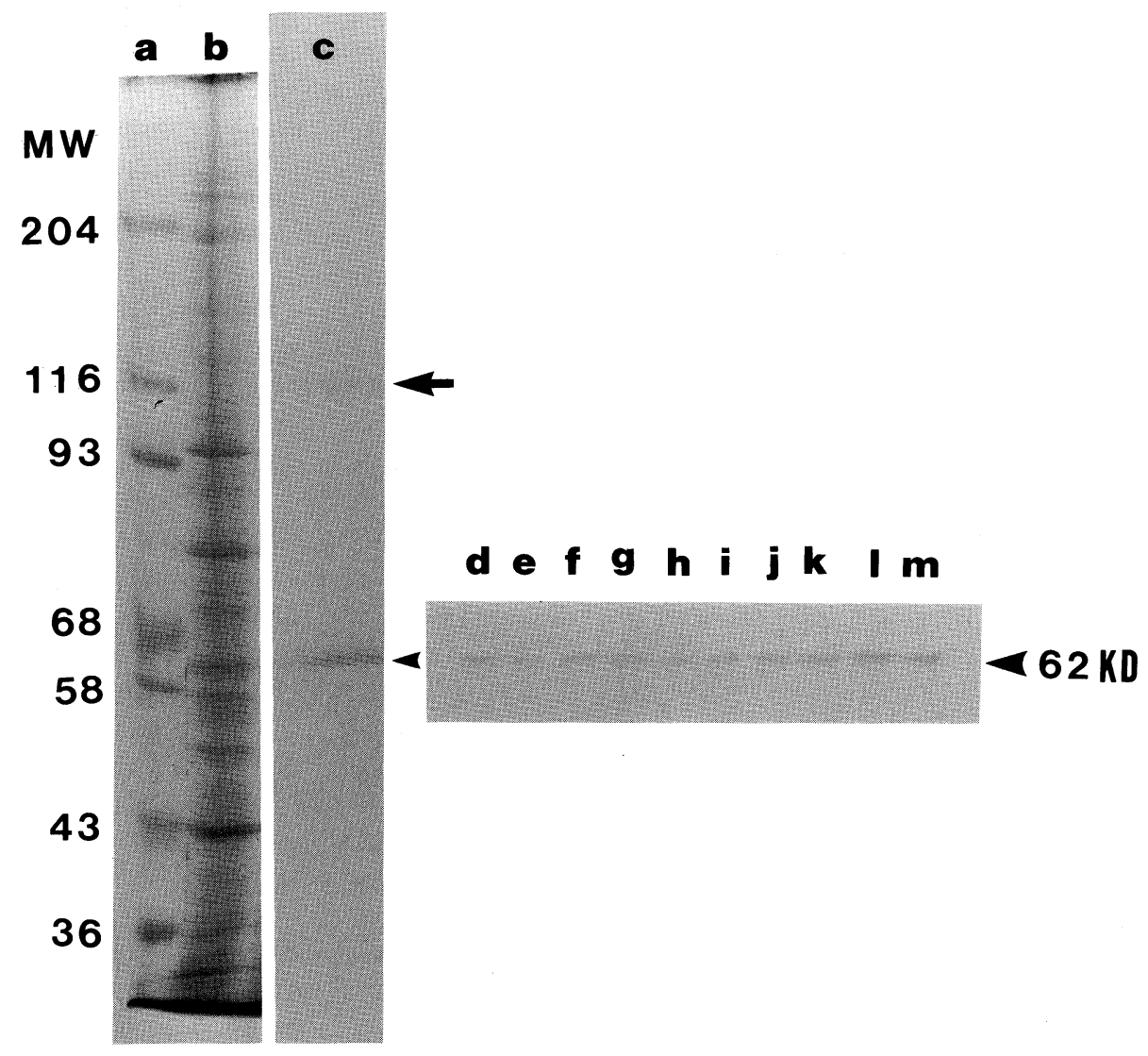

Fig. 6. Western blot analysis for c-fos protein in thyroid tissue, and follicle cells cultured on various substrata with or without $10 \mathrm{mU} / \mathrm{ml} \mathrm{TSH}$. Thyroid tissue (lanes b and c) and follicle cells cultured on plastic substratum (d and e), type I collagen (f and g), type IV collagen (h and i), fibronectin $(j$ and $k$ ) or laminin $(l$ and $m)$ in the presence $(e, g, i, k$ and $m$ ) or absence $(d, f, h, j$ and $l)$ of TSH were boiled with SDS, and the extracts were subjected to SDS-PAGE and immunoblot with an anti-c-fos antibody as described in Materials and Methods. Lanes a and b, Coomassie blue stain. lanes $\mathrm{c}-\mathrm{m}$, immunoblot. Lane a, molecular mass standards (MW) in kilodalton (KD). Arrowhead indicates $62 \mathrm{KD}$ c-fos protein. Arrow indicates the faint expression of endogeneous biotin-binding protein of about $116 \mathrm{KD}$. 
protein. TSH $(10 \mathrm{mU} / \mathrm{ml})$ did not affect the expression of the protein in the cells cultured on the substrata except for fibronectin, although TSH seemed to slightly enhance its expression in the cells on fibronectin (Fig. $6)$.

\section{DISCUSSION}

Our present study has shown that each of the ECM components tested (type I and IV collagen, fibronectin and laminin) induces differential effects on adhesion, proliferation, differentiation or c-fos protein expression of follicle cells. Interestingly, we have also demonstrated that TSH, a major effector for follicle cells, does not affect adhesion of the cells on any of the substrata or proliferation of the cells on fibronectin; nor does TSH affect c-fos protein expression of the cells on the substrata except for fibronectin under contact inhibition. Our results indicate that some behaviors of follicle cells are regulated not only by soluble factors, such as TSH, but also by insoluble ECM molecules.

Beta-1-integrin family plays a vital role in cell-toECM interaction. This group of cell surface heterodimers, cell adhesion molecules, is characterized by a common $\beta_{1}$ chain noncovalently associated with a distinctive $\alpha$ subunit (18). In the thyroid, Vitale et al. have shown that more than $97 \%$ of follicle cells express the $\beta_{1}$ chain, associated with a high level of $\alpha_{3}$ and very low levels of $\alpha_{1}, \alpha_{5}$ and $\alpha_{6}$ (42). This indicates that follicle cells exhibit mainly $\mathrm{VLA}_{3}$ (very late antigen ${ }_{3}, \beta_{1} \alpha_{3}$, a receptor for collagen, fibronectin, entactin or epiriglin $/$ kalinin) and express poorly a receptor $\left(\beta_{1} \alpha_{6}\right)$ specific for laminin (36). These findings are consistent with our results that adhesion of follicle cells to laminin at least at early culture stages is very poor, as compared with adhesion to other ECM molecules. However, the rate of cell adhesion to each substratum gradually increased during continuous cultures. It is conceivable that in order for the cells to become adhesive to a substratum, the cells themselves may change expressions of integrin receptors $(18,27)$.

In proliferation, we have shown that nuclear BrdU intake clearly increases in the cells cultured on type IV collagen, as compared with those cultured on laminin or fibronectin, although there is no statistical significance between type IV collagen and type I collagen or plastic substratum. Woodley et al. also have demonstrated that type IV collagen promotes proliferation of skin keratinocytes (43). At least in type IV collagen and laminin, which are the main components of basement membrane, their report and ours suggest that type IV collagen plays a more positive role in proliferation of follicle cells than laminin. In addition, TSH inhibited proliferation of follicle cells cultured on the substrata except for fibronectin. In contrast, proliferation of the cells cul- tured on fibronectin was not suppressed by TSH. The inhibition of proliferation by TSH is consistent with other reports in porcine follicle cells $(15,44)$. To our knowledge, our present study is the first demonstration that TSH does not affect proliferation of porcine follicle cells cultured on fibronectin, although at present the reason for that and its significance remain to be elucidated.

In a functional differentiation, we have shown that follicle cells cultured on laminin produce about 3 times as much $\mathrm{T}_{3}$ as compared with those on other ECM molecules. Some investigators have reported that laminin clearly induces functional differentiation of mammary epithelial cells or hepatocytes $(22,7)$. Miettinen et al. indicate that laminin expression of follicle cells is associated with the differentiated state of normal or neoplastic thyroid tissues (23). These studies and ours suggest that laminin plays a more positive role in a functional differentiation than type I and IV collagen or fibronectin. However, plastic substratum induced the highest level of $T_{3}$ production of the cells among all of the substrata examined. This suggests that some differentiative properties of follicle cells may be regulated at an appropriate level through cell-to-ECM interaction.

For the first time, we have shown in this study that follicle cells express c-fos protein even in contact inhibition. In addition, TSH does not affect c-fos protein expression in any of the cells cultured on the substrata except for fibronectin, although TSH seems to slightly enhance its expression in the cells on fibronectin. Many studies indicate that ECM regulates gene expression and signal transduction $(7,18,19,28)$. Our present study supports these outcomes. In this study, we have shown that laminin induces the highest levels of both c-fos protein expression and $\mathrm{T}_{3}$ production among the $\mathrm{ECM}$ molecules examined. Some studies indicate that c-fos protein expression is closely associated with the differentiated state of the epithelial cells in colon, salivary gland, kidney and thyroid $(2,34,37)$. Furthermore, laminin has been shown to clearly induce functional differentiation of hepatocytes and mammary epithelial cells, and to be related to the differentiated state of follicle cells $(7,22,23)$. These reports and ours suggest that c-fos protein expression of follicle cells under contact inhibition may be related to the laminin-induced cell differentiation.

In the cytologic localization of c-fos protein, we have shown that the protein is seen mainly in the nuclei of follicle cells, and occasionally and weakly in the cytoplasms. Roux et al. indicate that transport of c-fos protein from the cytoplasm, where it is synthesized, into the nucleus, depends on the stimulation of the cells by serum factors. In their study, c-fos protein is localized in the nucleus of fibroblasts fed with 10\% FCS, while the protein is detected in the cytoplasm of the serum- 
starved cells (26). This report and ours suggest that the cytologic localization of c-fos protein is transportable between the cytoplasm and the nucleus, which is controlled by extracellular signals. In addition, we have shown that c-fos protein expression in normal thyroid is stronger in smooth muscle cells of blood vessels than in follicle cells. Although the significance of this finding is unknown at present, the result will prompt further studies to clarify roles of $\mathrm{c}$-fos protein in the thyroid gland in more detail.

In conclusion, ECM has been shown to affect some biological behaviors of thyroid follicle cells in a TSH-dependent or TSH-independent manner. To further understand behaviors of the cells or thyroid diseases, it is hoped that our study will prompt investigations of the cells, involving both cell-to-soluble factor and cell-toECM interactions.

Acknowledgments. We thank Messrs. H. Ideguchi, S. Nakahara, F. Mutoh for technical assistance, and Messrs. T. Tanamachi and Y. Tateishi for photographs. We also thank Prof. K. Tohkaichi for reading of the manuscript and Dr. E. Sasatomi for helpful suggestions.

\section{REFERENCES}

1. Abate, C., LuK, D., Gentz, R., Rauscher, F.J., and Curran, T. 1990. Expression and purification of the leucine zipper and DNA binding domains of Fos and Jun: both Fos and Jun contact DNA directly. Proc. Natl. Acad. Sci. USA, 87: 1032-1036.

2. Birek, C., LUi, E., and DARDICK, I. 1993. c-fos oncogene underexpression in salivary gland tumors as measured by in situ hybridization. Am. J. Pathol., 142: 917-923.

3. CAPEN, C.C. 1991. Anatomy, comparative anatomy, and histology of the thyroid. In The Thyroid (Braverman, L.E. and Utiger, R.D., eds.). J.B. Lippincott, Philadelphia, pp.22-40.

4. Campana, D., Coustan-Smith, E., and Janossy, G. 1988. Double and triple staining methods for studying the proliferative activity of human B and $\mathrm{T}$ lymphoid cells. J. Immunol Methods, 107: 79-88.

5. Conde, E., Martin-Lacave, I., Utrilla, J.C., Moreno, A., Gonzalez-Campora, R., and Galera-Davidson, H. 1992. Mitotic activity of the endocrine cells in rat thyroid glands during postnatal life. Endocrinology, 131: 436-440.

6. Colletta, G., Cirafici, A.M., and Vecchio, G. 1986. Induction of the c-fos oncogene by thyrotropic hormone in rat thyroid cells in culture. Science, 233: 458-460.

7. CARON, J.M. 1990. Induction of albumin gene transcription in hepatocytes by extracellular matrix proteins. Mol. Cell Biol., 10: $1239-1243$.

8. Chambard, M., Gabrion, J., and Mauchamp, J. 1981. Influence of collagen gel on the orientation of epithelial cell polarity: Follicle formation isolated thyroid cells and from performed monolayers. J. Cell Biol., 91: 157-166.

9. Chiu, R., Boyle, W.J., Meek, J., Smeal, T., Hunter, T., and KARIN, M. 1988. The c-fos protein interacts with c-jun/AP-1 to stimulate transcription of AP-1 responsive genes. Cell, 54: 541-552.

10. Curran, T., Peters, G., Van Beveren, C., Teich, N.M., and VERMA, I.M. 1982. FBJ murine osteosarcoma virus: identification and molecular cloning of biologically active proviral DNA.

\section{J. Virol., 44: 674-682.}

11. Durban, E.M. 1990. Mouse submandibular salivary epithelial cell growth and differentiation in long-term culture: influence of the extracellular matrix. In Vitro Cell. Dev. Biol., 26: 33-43.

12. Dumont, J.E., Maenhaut, C., Pirson, I., Baptist, M., and ROGER, P.P. 1991. Growth factors controlling the thyroid gland. Baillieres Clin. Endocrinol. Metab., 5: 727-754.

13. Fujiyama, C., Masaki, Z., and Sugihara, H. 1995. Reconstruction of the urinary bladder mucosa in three-dimensional collagen gel culture: fibroblast-extracellular matrix interactions on the differentiation of transitional epithelial cells. J. Urol., 153: 2060-2067.

14. Finkel, M.P., BISKIS, B.O., and Tinkins, P.B. 1966. Virus induction of osteosarcomas in mice. Science, 151: 698-701.

15. Gärtner, R., Greil, W., Demharter, P., and Horn, K. 1985. Involvement of cyclic AMP, iodine and metabolites of arachidonic acid in the regulation of cell proliferation of isolated porcine thyroid follicle cells. Mol. Cell Endocrinol., 42: $145-155$.

16. Githens, S., Schexnayder, J.A., Desai, K., and Patke, C.L. 1989. Rat pancreatic interlobular duct epithelium: isolation and culture in collagen gel. In vitro Cell. Dev. Biol., 25: 679688.

17. Heldin, N.E. and Westermark, B. 1988. Epidermal growth factor, but not thyrotropin, stimulates the expression of c-fos and c-myc messenger ribonucleic acid in porcine thyroid follicle cells in primary culture. Endocrinology, 122: 1042-1046.

18. HyNES, R.O. 1992. Integrins: Versatility, modulation, and signaling in cell adhesion. Cell, 69: 11-25.

19. Juliano, R.L. and HASKILL, S. 1993. Signal transduction from the extracellular matrix. J. Cell Biol., 120: 577-585.

20. Kawamura, H. and Ichihara, I. 1987. Primary culture of epithelial cells derived from the rat ventral prostate: formation of three-dimensional acinus-like structures in collagen gel. Prostate, 10: 153-161.

21. Kawamura, Y., Yoshida, K., and Nakanuma, Y. 1989. Primary culture of rabbit galbladder epithelial cells in collagen gel matrix. Lab. Invest., 61: 350-356.

22. LiN, C.Q. and Bissell, M. 1993. Multi-faceted regulation of cell differentiation by extracellular matrix. FASEB. J., 7: 773743.

23. Miettinen, M. and Virtanen, I. 1984. Expression of laminin in thyroid gland and thyroid tumor: An immunohistologic study. Int. J. Cencer, 34: 27-30.

24. Martin, R.G. and Timpl, R. 1987. Laminin and other basement membrane components. Annu. Rev. Cell Biol., 3: 57-85.

25. Montesano, R., ORCI, L., and Vassalli, P. 1983. In vitro rapid organization of endothelial cells into capillary-like networks is promoted by collagen matrices. J. Cell Biol., 97: 1648-1652.

26. Roux, P., Blanchard, J.M., Fernandez, A., Lamb, N., JeAnteur, P., and PiechaczyK, M. 1990 . Nuclear localization of c-fos, but not v-fos protein, is controlled by extracellular signals. Cell, 63: 341-351.

27. RaGHOw, R. 1994. The role of extracellular matrix in postinflammatory wound healing and fibrosis. FASEB. J., 8: 823-831.

28. Streuli, C.H., Schmidhauser, C., Kobrin, M., Bissell, M.J., and DERYNCK, R. 1993. Extracellular matrix regulates expression of the TGF- $\beta_{1}$ gene. J. Cell Biol., 120: 253-260.

29. Sassone-Corsi, P., Ranson, L.K., Lamph, W.W., and Verma, I.M. 1988. Direct interaction between Fos and Jun nuclear oncoproteins: role of the leucine zipper domain. Nature, 336: 692695.

30. Sugihara, H., Yonemitsu, N., Toda, S., Miyabara, S., 
Funatsumaru, S., and Matsumoto, T. 1988. Unilocular fat cells in three-dimensional collagen gel matrix culture. J. Lipid Res., 29: 691-697.

31. Sugihara, H., Toda, S., Miyabara, S., Kusaba, Y., and MinAmI, Y. 1991. Reconstruction of the skin in three-dimensional collagen gel matrix culture. In Vitro Cell. Dev. Biol., 27A: $142-146$.

32. Sugihara, H., Toda, S., Miyabara, S., Fujiyama, C., and YoNEMTSU, N. 1993. Reconstruction of alveolus-like structure from alveolar type II epithelial cells in three-dimensional collagen gel matrix culture. Am. J. Pathol., 142: 783-792.

33. Sugihara, H. and Toda, S. 1994. Reconstruction culture. In Cell and Tissue Culture: Laboratory Procedures (Griffiths, J.B., Doyle, A. and Newell, D.G., eds.). John Wiley and Sons Limited, Baffins Lane, England, pp3A: 2.1-12.

34. Sugio, K., Kurata, S., Sasaki, M., Soejima, J., and Sasazuki, T. 1988. Differential expression of c-myc gene and c-fos gene in premalignant and malignant tissues from patients with familial polyposis coli. Cancer Res., 48: 4855-4861.

35. Tramontano, D., Chin, W.W., Mose, A.C., and Ingbar, S.H. 1986. Thyrotropin and dibutyryl cyclic AMP increase levels of c-myc and c-fos mRNA in cultured rat thyroid cells. J. Biol. Chem., 261: 3919-3922.

36. Tryggvason, K. 1993. The laminin family. Curr. Opin. Cell Biol., 5: 877-882.

37. Terrier, P., Sheng, Z.M., Schlumberger, M., Tubiana, M., Caillous, B., Travagli, J.P., Fragu, P., Parmentier, C., and Riou, G. 1988. Structure and expression of c-myc and c-fos proto-oncogenes in thyroid carcinoma. Br. J. Cancer, 57: 4347.

38. Toda, S. and Sugihara, H. 1990. Reconstruction of thyroid follicles from isolated porcine follicle cells in three-dimensional collagen gel culture. Endocrinology, 126: 2027-2034.
39. Toda, S., Yonemitsu, N., Hikichi, Y., Koike, N., and Sugihara, H. 1992. Differentiation of human thyroid follicle cells from normal subjects and Basedow's disease in three-dimensional collagen gel culture. Path. Res. Pract., 188: 874882.

40. Toda, S., Yonemitsu, N., Minami, Y., and Sugihara, H. 1993. Plural cells organize thyroid follicles through aggregation and linkage in collagen gel culture of porcine follicle cells. Endocrinology, 133: 914-920.

41. Tominaga, T., Cruz, J.D., Burrow, G.N., and Meinkoth, J.D. 1994. Divergent patterns of immediate early gene expression in response to thyroid-stimulating hormone and insulinlike growth factor I in Wistar rat thyrocytes. Endocrinology, 135: 1212-1219.

42. Vitale, M., Bassi, V., Fenzi, G., Macchia, P.E., Salzano, S., and Rossi, G. 1993. Integrin expression in thyroid cells from normal glands and nodular goiters. J. Clin. Endocrinol. Metab., 76: 1575-1579.

43. Woodley, D.T., Wynn, K.C., and O'Keefe, E.J. 1990. Type IV collagen and fibronectin enhance human keratinocyte thymidine incorporation and spreading in the absence of soluble growth factors. J. Invest. Dermatol., 94: 139-143.

44. Westermark, K., Westermark, B., Karlsson, F.A., and ERICSON, L.E. 1986. Location of epidermal growth factor receptors on porcine thyroid follicle cells and receptor regulation by thyrotropin. Endocrinology, 118: 1040-1046.

45. Yang, J., Richards, J., Bowman, P., Guzman, R., Enami, J., McCormick, K., Hamamoto, S., Pitelka, D., and Nandi, S. 1979. Sustained growth and three-dimensional organization of primary mammary tumor epithelial cells embedded in collagen gel. Proc. Natl. Acad. Sci. USA, 76: 3401-3405.

(Received for publication, May 25, 1995 and in revised form, June 30, 1995) 